九州大学学術情報リポジトリ

Kyushu University Institutional Repository

\title{
Exergy Analysis of Coal-Fired Power Plants in Ultra Supercritical Technology versus Integrated Gasification Combined Cycle
}

Wahid, Abdul

Department of Chemical Engineering, Faculty of Engineering, Universitas Indonesia

Mustafida, Ratna, Dwi

Department of Chemical Engineering, Faculty of Engineering, Universitas Indonesia

Husnil, Amalia, Yuli

Department of Chemical Engineering, Faculty of Engineering, Universitas Indonesia

https://doi.org/10.5109/2740939

出版情報: Evergreen. 7 (1)，pp.32-42，2020-03. 九州大学グリーンテクノロジー研究教育センター バージョン：

権利関係 : 


\title{
Exergy Analysis of Coal-Fired Power Plants in Ultra Supercritical Technology versus Integrated Gasification Combined Cycle
}

\author{
Abdul Wahid ${ }^{1, *}$, Dwi Ratna Mustafida ${ }^{1}$, Yuli Amalia Husnil ${ }^{2}$ \\ ${ }^{1}$ Department of Chemical Engineering, Faculty of Engineering, Universitas Indonesia, \\ Depok 16424, Indonesia \\ ${ }^{2}$ Department of Chemical Engineering, Institut Teknologi Indonesia, \\ Tangerang Selatan 15314, Indonesia \\ *Author to whom correspondence should be addressed: \\ E-mail:Wahid@che.ui.ac.id
}

(Received October 31, 2019; Revised December 16, 2019; accepted February 24, 2020).

\begin{abstract}
This study evaluates and compared the performance of coal-fired power plants in ultrasupercritical (USC) versus integrated gasification combined cycle (IGCC). System execution in terms of net control created, exergy examination was performed to coordinate the vitality loss dispersion of this system. Base on the exergy adjust condition. The IGCC system is modeled and simulated with post-combustion capture and both used sub-bituminous coal from the Indramayu PLTU. The result display that with the same amount of raw materials ( $20 \mathrm{ton} / \mathrm{h}$ coal $)$ the IGCC generated great net power than USC. IGCC produced net power of $42 \mathrm{MW}$ and USC of $22 \mathrm{MW}$. The highest exergy loss in the gasifier, $\mathrm{H}_{2} \mathrm{~S}$ Removal and Carbon Capture for IGCC and in Boiler, Steam Turbine system, and condenser for USC. The total exergy efficiency for IGCC was $41.51 \%$ and $33.71 \%$ in USC.
\end{abstract}

Keywords: Coal-fired power plants; USC; IGCC, Exergy analysis

\section{Introduction}

Electricity consumption increases regardless of the economic development stage of each country and region ${ }^{1)}$ included Indonesia. Indonesia's GDP per capita has increased rapidly in the 2000s and beyond. Indonesia's economic growth is expected to continue to increase electricity consumption to reach 491 terawatt hours (TWh) in 2030. Therefore, electricity generation capacity needs to be increased by 4.1 gigawatts (GW) per year, of which $50 \%$ of the total installed capacity is Coal Power Plant ${ }^{2}$.

Combustion of fuel produced high exhaust emission especially $\mathrm{CO}_{2}$ gases which increased pollutant concentration in air. Coal contributed $44 \%$ of total global $\mathrm{CO}_{2}$ emissions and became the largest source of GHG (greenhouse gas) emissions ${ }^{3)}$ such as carbon dioxide $\left(\mathrm{CO}_{2}\right)$, methane $\left(\mathrm{CH}_{4}\right)$, nitrous oxide $\left(\mathrm{N}_{2} \mathrm{O}\right)$, ozone $\left(\mathrm{O}_{3}\right)$, and chlorofluorocarbons $(\mathrm{CFCs})^{27)}$. To reduce these pollutants, it is very important to increase energy efficiency in coal-fired power plants ${ }^{4}$.

Reducing $\mathrm{CO}_{2}$ gas emissions from the energy sector in principle can be done in several ways, namely the use of energy-efficient technologies or use Clean Coal
Technology (CCT), fuel substitutions from low carbon (C) to higher carbon $(\mathrm{C})$ or fuels with lower carbon fractions, and the third is $\mathrm{CO}_{2}$ or carbon capture and storage $(\mathrm{CCS})^{5)}$.

Clean Coal Technology (CCT) does not eliminate emissions to zero or close to zero, but rather means that there are fewer emissions. Even so, clean coal technologies can reduce emissions from several pollutants and waste and increase the energy produced from each ton of coal. Thus, the CCT technology for a coal power plant is now more efficient and environmentally friendly. besides using clean coal technology, it is necessary to add carbon capture to increase its efficiency. the purpose of carbon capture is to collect from various streams and is usually liquefied to facilitate storage ${ }^{26)}$ or usually injected into the depths of the ocean and oil wells that are no longer in use.

The application of clean coal technology is useful for developing more efficient thermal systems, namely, to produce the same amount of energy, fewer coal inputs are needed, thus extending the availability of energy sources and producing emissions that are far lower than conventional technology. Various types of clean coal technology are still under development in order to provide a method that is environmentally satisfying in the use of 
coal, especially for electricity generation such as $\mathrm{USC}^{4,6-}$ 11), IGCC 12-14), and Integrated Coal Gasification of Fuel Cell Combined Cycle (IGFC) ${ }^{15)}$. In China use of coal as gasification is considered a promising technology and can handle energy needs and climate change ${ }^{23)}$.

For the IGCC plant, the fuel source is also derived from low-grade solid fuels (biomass, wood, refinery residues, and petroleum cokes) $)^{11)}$. So, in this study will be used lowquality coal (sub-bituminous) from Indramayu PLTU. From report Huaneng Greengen Co the result shows that IGCC has higher efficiency thermal than USC but the generating capacity of both is different (USC is $1000 \mathrm{MW}$ and IGCC is $250 \mathrm{MW})^{16)}$ so it cannot be compared.

$\mathrm{M}$ Asif et al. ${ }^{12)}$ simulated and compared in three configurations: IGCC without $\mathrm{CO}_{2}$ capture, IGCC with pre- combustion capture (IGCC-eCC), and IGCC with post-combustion capture (IGCC-oCC). IGCC-oCC is more efficient than IGCC-eCC, namely $561 \mathrm{MW}$ and 518 MW, respectively. M. Knoope et $\mathrm{al}^{25)}$. investigate the technological and economic prospects of IGCC and Fischer-Tropsch (FT) liquid production with and without CCS, results indicate that substantial cost reductions and performance improvements are possible, especially for IGCC with CCS. Y. Liu et al. ${ }^{4}$ studied that thermodynamic analysis of a modified system for a 1000 MW single reheat ultra-supercritical thermal power plant, results show that the exit temperature of flue gas from the boiler can be reduced to a lower value without cold end corrosion and clog. The power generation efficiency of the power plant of $48.35 \%$ is achieved, which is $1.27 \%$ points higher than that of the reference unit at the same capacity. Zhou et al. ${ }^{7)}$ studied that Parametric analysis and process optimization of steam cycle in double reheat ultrasupercritical power plants, the results showed that the power generation efficiency of the double reheat power plant could increase by 0.49 percentage point by parametric and process optimization.

Most of the works depended adjust investigation on energy based. These considers based on the vitality base strategies are simple to get it, but as it were the quantitative variety of vitality is considered, and its subjective variety is ignored. Subsequently, the application of such a strategy for surveying the enhancement conceivable outcomes of a prepare can result in a mutilated vision of the inquired about the framework and the irreversibility of forms inside the framework cannot be characterized ${ }^{9}$. By differentiate, exergy examination can characterize the work potential of a framework. Exergy is characterized as the most extreme hypothetical valuable work gotten with the reference or dead state, exergy investigation based on the moment law of thermodynamics can precisely appear the development and utilization of a device ${ }^{6,9)}$.

The purpose of this study to perform of an IGCC-oCC and USC process was developed using UniSim Design ${ }^{\circledR}$ R450 and Promax ${ }^{\circledR}$ 4.0. IGCC and USC technology was evaluated and compared. Performance of the system in terms of net power produced, to performed energy loss distribution of this system use the exergy analysis. Base on the exergy balance equation, exergy efficiency, exergy distribution and efficiency of the unit were determined.

\section{Description and Calculation Models}

\subsection{Description process of IGCC}

The Process flow diagram of the IGCC prepare utilized within the investigation is shown in Fig. 1. The process consists of five main blocks: coal measuring and slurry planning, gasification unit, syngas cooling and cleaning unit, Acid Gas Removal (AGR) unit, $\mathrm{CO}_{2}$ gas cleaning unit and combined cycle power segment. In the step one of the preparation coal with crushing and mixing of coal with water. The coal slurry is fed to the gasifier unit added with pure $\mathrm{O}_{2} 95 \%$ and steam to produce raw syngas, raw syngas is fed to syngas cooling and cleaning to remove $\mathrm{H}_{2} \mathrm{~S}$ gas using an absorption unit with MDEA solvent. syngas that has been separated will be burned in the combustor unit using dry air then the combustion gas will be used as a driving force in the turbine gas unit to produce electricity. The turbine output gas will be used as a heater in the Heat Recovery Steam Generation (HRSG) unit to produce steam. Steam produced will be used as a driving force for steam turbines to produce electricity. the gas used to produce steam will be fed to the $\mathrm{CO}_{2}$ removal unit.

The reason for utilizing unadulterated oxygen within the gasifier is to extend the warming esteem of the syngas and to diminish the syngas volume. The low volume of raw syngas is moderately simple to handle within the heat recuperation area and in acid gas removal unit. Also, the by and large taken a toll of the IGCC framework diminished due to the little hardware measure in gasification, AGR, and syngas cooling units ${ }^{12)}$.

The traditional Sulphur removal processes utilize a variety of commercial solvents, which be categorized into three general types: chemical, physical, and hybrid solvents ${ }^{18)}$.

Steam produced in the HRSG unit is divided into three parts related to pressure, namely high pressure (HP), intermediate pressure (IP), low pressure (LP). To drive the steam turbine used the HP superheated steam from HRSG. And then to produce superheated steam used the IP and LP steam reheated in the HRSG ${ }^{12)}$.

\subsection{Description Process of USC}

The Process flow diagram of the USC process used in the analysis is shown in Fig. 2. The process consists of two main blocks: boiler subsystem and turbine subsystem ${ }^{8}$. The coal is fed to the boiler, where the feed water from the regenerative system from the steam turbine is heated to the specified conditions. The power plant comprises highpressure turbines (HPT1, HPT2), intermediate-pressure turbines (IPT1, IPT2), and low- pressure turbines (LPT14). The Flue gas prepares to $\mathrm{CO}_{2}$ Capture to separate $\mathrm{CO}_{2}$ 
and $\mathrm{H}_{2} \mathrm{~S}$ with the DEA solvent ${ }^{24)}$.

\subsection{Simulation Models and Main Assumptions}

An IGCC and USC plant integrated with $\mathrm{CO}_{2}$ capture are simulated using UniSim Design ${ }^{\circledR}$ R450 and Promax ${ }^{\circledR}$ 4.0 program simulation software. The following are some of the design parameters and assumptions used in this study:

- The model is based on a steady state

- Coal particles feed in standard conditions $\left(30^{\circ} \mathrm{C}\right.$ and 1 atm)

- $\quad$ Feed coal use rheology of coal-water slurries ${ }^{17)}$

- A chemical reaction occurs in a state of equilibrium, and there is no decrease in pressure

- In the heat exchanger, there is a pressure drop of 5 psi
- The composition of syngas products and process model based on experimental data ${ }^{12,18)}$

- The boiler model is based on a reference model of Yang, et al. and Zhou, et al. ${ }^{8,7)}$

- The Air Separation Unit (ASU) is not modeled

- The Cryogenic is based on a reference model (Air Liquide Indonesia. PT)

- In the Gasification Reactor used a UniSim Design ${ }^{\circledR}$ R450

- Pump efficiency of $65 \%$

- Turbine efficiency and compressor of $75 \%$

- Coal specification was obtained from the Indramayu PLTU (Table 1)

The operating conditions and design used of the IGCC plant shown in Table 2 and USC plant shown in Table 3.

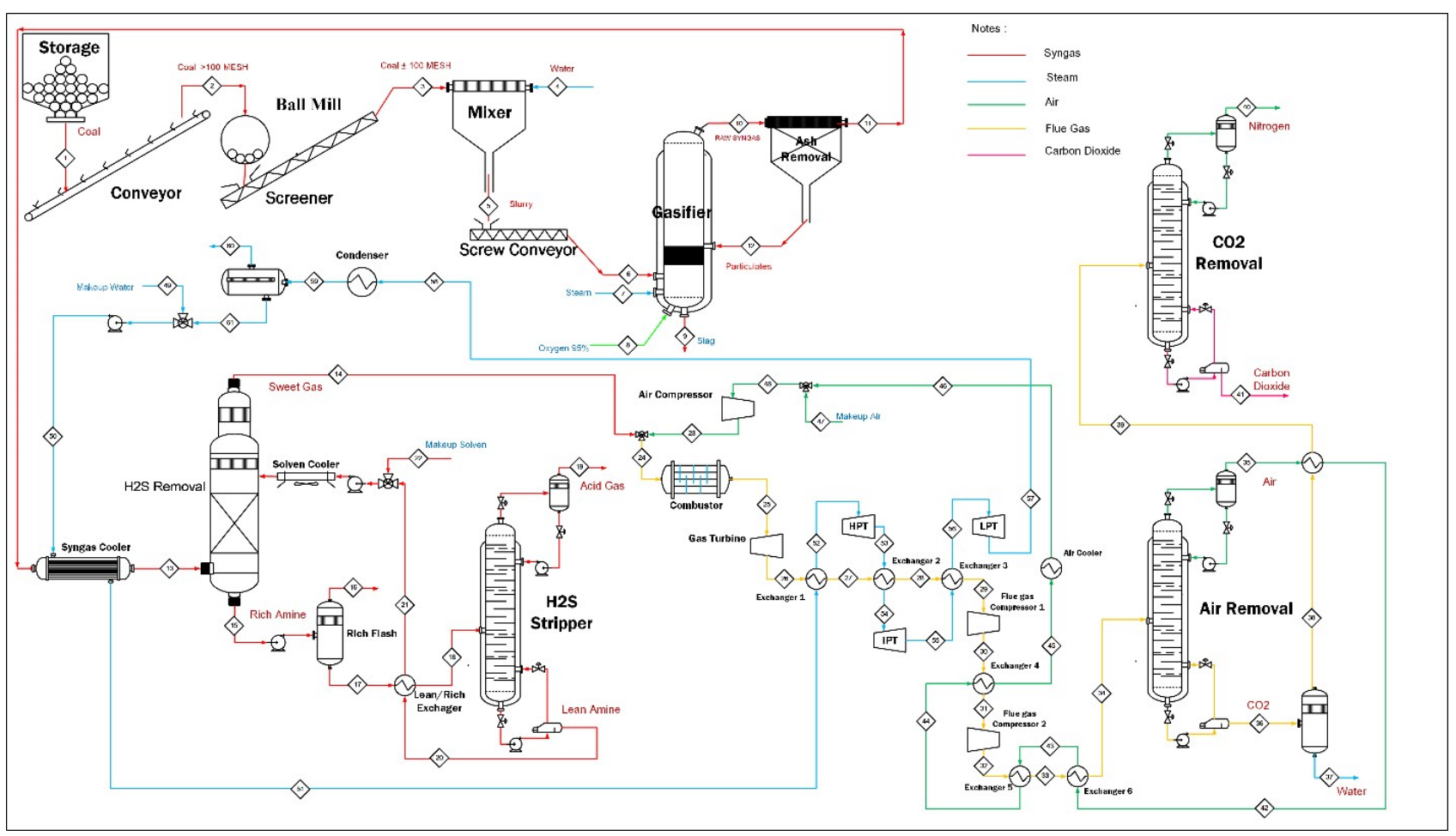

Fig. 1: Process flow diagram of the IGCC

\subsection{Calculation method}

exergy is a form of the second law of thermodynamics related to energy quality, where not all energy produced can be used or produce $100 \%$ work, but there will be a loss of good environment. The exergy loss can be form of chemical exergy, physical exergy, potential exergy and kinetic exergy. For the exergy-based analysis, the physical, chemical, potential, kinetic and total exergies of all streams are calculated based on the results from the simulation ${ }^{12,19,21-22)}$.

$$
E x_{\text {total }}=E x_{p h}+E x_{k}+E x_{p}+E x_{c h}
$$

Because there is no kinetic and potential exegesis so the two exergy can be ignored and the equation becomes:

$E x_{\text {total }}=E x_{p h}+E x_{c h}$

The following is the equation used to calculate physical exergy:

$$
E x_{p h}=\left(h-h_{0}\right)-T_{0}\left(s-s_{0}\right)
$$

The following is the equation used to calculate chemical exergy for gas mixture:

$$
E x_{c h, g a s}=\sum x_{i} E x_{c h, i}+R T_{0} \sum x_{i} \ln x_{i}
$$

The equation used to calculate Chemical exergy of the 
coal is ${ }^{12)}$ :

$E x_{c h, \quad f u e l}=\left(L H V+w_{H 2 O} L H_{w}\right) \emptyset_{d r y}+9417 w_{S}$

$\emptyset_{d r y}=0.1882 \frac{w_{h}}{w_{c}}+0.061 \frac{w_{o x}}{w_{c}}+0.0404 \frac{w_{n}}{w_{c}} \quad+$ 1.0437

(6)
The following is the equation used to calculate exergy efficiency:

$$
\eta=\frac{\text { Exergy Product }}{\text { Exergy Input }}
$$

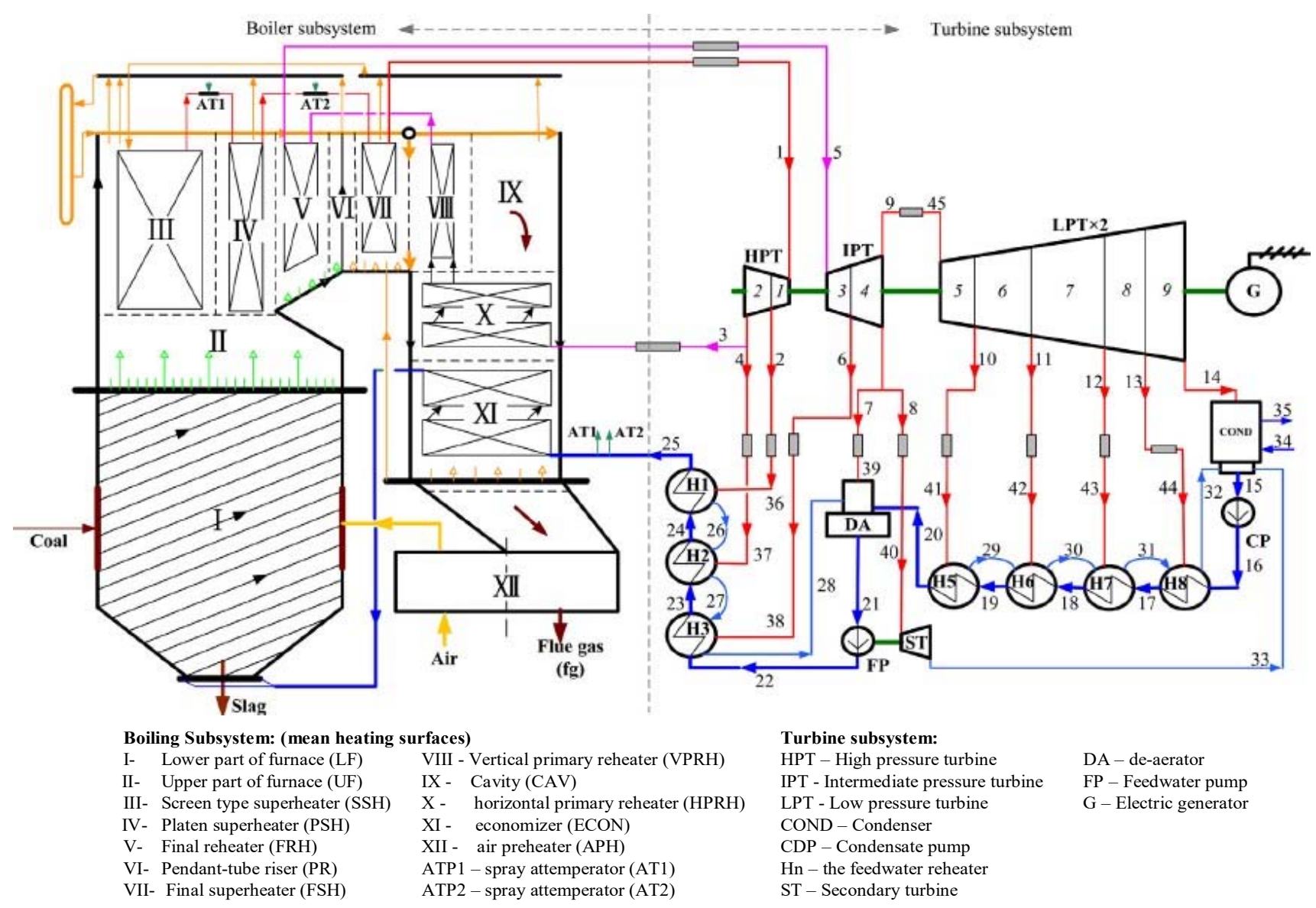

Fig. 2: Process flow diagram of the USC

Table 1. Composition analysis of coal

\begin{tabular}{cc}
\hline Composition & Value (\% wt.) \\
\hline Moisture & 14.34 \\
Fixed carbon & 37.63 \\
Volatile matter & 43.47 \\
Ash & 4.56 \\
C & 55.42 \\
H & 4.20 \\
N & 0.71 \\
S & 0.1 \\
O & 20.67 \\
Ash & 4.56 \\
Calorific value, HHV $(\mathrm{kcal} / \mathrm{kg})$ & 4236 \\
\hline
\end{tabular}


Table 2. Assumptions and operating conditions for simulation of IGCC

\begin{tabular}{|c|c|c|c|}
\hline Units & Model Simulation & Parameters & Value \\
\hline \multirow[t]{8}{*}{ Reactor } & Gasifier Reactor & Pressure $(\mathrm{kPa})$ & 2000 \\
\hline & & Temperature $\left({ }^{\circ} \mathrm{C}\right)$ & 1063 \\
\hline & & Composition: & \\
\hline & & Coal $65 \%$ wt. $(\mathrm{kg} / \mathrm{h})$ & 20000 \\
\hline & & Air $35 \%$ wt. $(\mathrm{kg} / \mathrm{h})$ & 7000 \\
\hline & & Oxygen $(95 \%), 35 \%$ wt. $(\mathrm{kg})$ & 7000 \\
\hline & & Steam $(\mathrm{Kg} / \mathrm{h})$ & 8000 \\
\hline & & Syngas out (kg/h) & 40696.13 \\
\hline \multirow[t]{5}{*}{ Combustor } & Combustor & Pressure $(\mathrm{kPa})$ & 1800 \\
\hline & & Temperature $\left({ }^{\circ} \mathrm{C}\right)$ & 763.8 \\
\hline & & Composition: & \\
\hline & & Syngas (kg/h) & 26557 \\
\hline & & Air (kg) & 978393 \\
\hline
\end{tabular}

Type Combustor (Gibs Minimization) Gibs set (burner)

\begin{tabular}{|c|c|c|c|}
\hline $\mathrm{H}_{2} \mathrm{~S}$ & $\mathrm{H}_{2} \mathrm{~S}$ absorber & Mass solvent (MDEA) (kg) & 43830.63 \\
\hline \multirow[t]{18}{*}{ Removal } & & Temperature $\left({ }^{\circ} \mathrm{C}\right)$ & 30 \\
\hline & & Pressure $(\mathrm{kPa})$ & 1965.53 \\
\hline & & \multicolumn{2}{|c|}{ Ideal Stage Column Type (TSWEET Kinetics) } \\
\hline & & Pressure Drop per tray (Psi) & 5 \\
\hline & & Number of trays & 7 \\
\hline & & Diameter (m) & 1.3 \\
\hline & & Tray Spacing (m) & 0.6 \\
\hline & & Weir Height $(\mathrm{cm})$ & 7 \\
\hline & & Total Height (m) & 12.6 \\
\hline & \multirow[t]{5}{*}{ Stripper } & Temperature $\left({ }^{\circ} \mathrm{C}\right)$ & 100 \\
\hline & & Pressure $(\mathrm{kPa})$ & 172.37 \\
\hline & & \multicolumn{2}{|c|}{ Ideal Stage Column Type (TSWEET Stripper) } \\
\hline & & Number of trays & 10 \\
\hline & & Pressure Drop per tray (Psi) & 4 \\
\hline & $\mathrm{HE}$, & Pressure Drop (Psi) & 5 \\
\hline & Cooler, & Pressure Drop (Psi) & 5 \\
\hline & Pump, & Pump Efficiency (\%) & 65 \\
\hline & Makeup Solvent & Mass (Kg/h) & 5481.31 \\
\hline HRSG & $\begin{array}{c}\text { preheater, } \\
\text { economizers, evaporator } \\
\text { superheater }\end{array}$ & Pressure Drop (Psi) & 5 \\
\hline $\mathrm{CO} 2$ & Distillation Cryogenic 1 & Temperature $\left({ }^{\circ} \mathrm{C}\right)$ & -70 \\
\hline \multirow[t]{6}{*}{ Removal } & & Pressure $(\mathrm{kPa})$ & 480 \\
\hline & & Number of trays & 10 \\
\hline & Distillation Cryogenic 2 & Temperature $\left({ }^{\circ} \mathrm{C}\right)$ & -120 \\
\hline & & Pressure $(\mathrm{kPa})$ & 480 \\
\hline & & Number of trays & 5 \\
\hline & & Mass CO2 (kg/h) & 40097.12 \\
\hline
\end{tabular}


Table 3. Assumptions and operating conditions for simulation of USC

\begin{tabular}{|c|c|c|c|}
\hline Unit & Model Simulation & Parameter & Value \\
\hline \multirow[t]{9}{*}{ Boiler } & Combustor & Pressure $(\mathrm{kPa})$ & 465.53 \\
\hline & & Temperature $\left({ }^{\circ} \mathrm{C}\right)$ & 1568 \\
\hline & & Composition: & \\
\hline & & Coal $(\mathrm{kg} / \mathrm{h})$ & 20000 \\
\hline & & $\operatorname{Air}(\mathrm{kg} / \mathrm{h})$ & 336000 \\
\hline & Type Combustor (Gib & Minimization) Gibs set(burner) & \\
\hline & (WSPSH), (FRH), & Pressure Drop & 5 \\
\hline & (FSH), Economizer, & (Psi) & 30000 \\
\hline & $(\mathrm{PRH}),(\mathrm{APH})$ & Pressure $(\mathrm{kPa})$ & \\
\hline \multirow[t]{19}{*}{$\mathrm{H}_{2} \mathrm{~S}$ dan $\mathrm{CO}_{2}$ Removal } & Absorber & Mass solvent $(\mathrm{DEA})(\mathrm{kg} / \mathrm{h})$ & 756000 \\
\hline & & Temperature $\left({ }^{\circ} \mathrm{C}\right)$ & 30 \\
\hline & & Pressure $(\mathrm{kPa})$ & 465.53 \\
\hline & & \multicolumn{2}{|c|}{ Ideal Stage Column Type (TSWEET Kinetics) } \\
\hline & & Pressure Drop per tray (Psi) & 5 \\
\hline & & Number of trays & 15 \\
\hline & & Diameter (m) & 4 \\
\hline & & Tray Spacing (m) & 0.6 \\
\hline & & Weir Height $(\mathrm{cm})$ & 7 \\
\hline & & Total Height (m) & 27 \\
\hline & Stripper & Temperature $\left({ }^{\circ} \mathrm{C}\right)$ & 120 \\
\hline & & Pressure $(\mathrm{kPa})$ & 175.53 \\
\hline & & \multicolumn{2}{|c|}{ Ideal Stage Column Type (TSWEET Stripper) } \\
\hline & & Number of trays & 10 \\
\hline & & Pressure Drop per tray (Psi) & 4 \\
\hline & $\mathrm{HE}$ & Pressure Drop (Psi) & 5 \\
\hline & Cooler, & Pressure Drop (Psi) & 5 \\
\hline & Pump & Pump Efficiency (\%) & 65 \\
\hline & Makeup Solvent & Mass $(\mathrm{Kg} / \mathrm{h})$ & 3311.53 \\
\hline \multirow[t]{2}{*}{ HPT } & 2 Turbine & $\mathrm{P}$ in $(\mathrm{kPa})$ & 29212.1 \\
\hline & & $\mathrm{P}$ out $(\mathrm{kPa})$ & 4601.47 \\
\hline \multirow[t]{2}{*}{ IPT } & 2 Turbine & $\mathrm{P}$ in $(\mathrm{kPa})$ & 4498.05 \\
\hline & & $\mathrm{P}$ out $(\mathrm{kPa})$ & 1000 \\
\hline \multirow[t]{2}{*}{ LPT } & 4 Turbine & $\mathrm{P}$ in $(\mathrm{kPa})$ & 1000 \\
\hline & & Pout $(\mathrm{kPa})$ & 40 \\
\hline
\end{tabular}

\section{Results and Discussions}

Fig. 3. Display the simplified schematic as a result of the simulation with IGCC technology and Fig. 4. Display the simplified schematic as a result of the simulation with USC technology.

Total power produced, and the total power consumed in IGCC and USC system is shown in Fig. 5. And The power consumed, and the power produced in IGCC and USC section are shown in Fig. 6 and Fig. 7. in IGCC net power produced was $42 \mathrm{MW}$ and $22 \mathrm{MW}$ in USC. The results indicated that the power produced from IGCC was highest than USC. In research conducted by Asif et. al. ${ }^{12)}$, coal is needed at $157860 \mathrm{~kg} / \mathrm{h}$ to produce a net power of $561 \mathrm{MW}$ using IGCC technology. while Y. Yang et.al ${ }^{8)}$ requires coal of $250740 \mathrm{~kg} / \mathrm{h}$ to produce a net power of $670 \mathrm{MW}$. So that in the next study optimization of coal flow rate is needed to produce a more optimum net power.
The maximum power produced in the GT was 148.48 MW. 20.63 MW and 22.14 MW in consecutive contained in ST IGCC and USC. 1.022 MW consumed in the gas turbine compressor of the Combustor for IGCC, for $\mathrm{O}_{2}$ compression for IGCC was $0.95 \mathrm{MW}$ and consumed in Cryogenic $\mathrm{CO}_{2}$ Separation was $125 \mathrm{MW}$. Nearly $73.92 \%$ of the total power produced consumed in Cryogenic $\mathrm{CO}_{2}$ Separation, consumed in pumps $0.04 \mathrm{MW}, 0.0008 \mathrm{MW}$ for coal slurry preparation and consumed in the main $\mathrm{CO}_{2}$ compressor for USC was 20.84 MW Shown in Fig. 6. The results $73.92 \%$ was consumed in the Cryogenic $\mathrm{CO}_{2}$ Separation of the total power produced and in USC is illustrated in Fig. 7. The results shown that $0.6 \%$ consumed in the pump of the total power produced. 


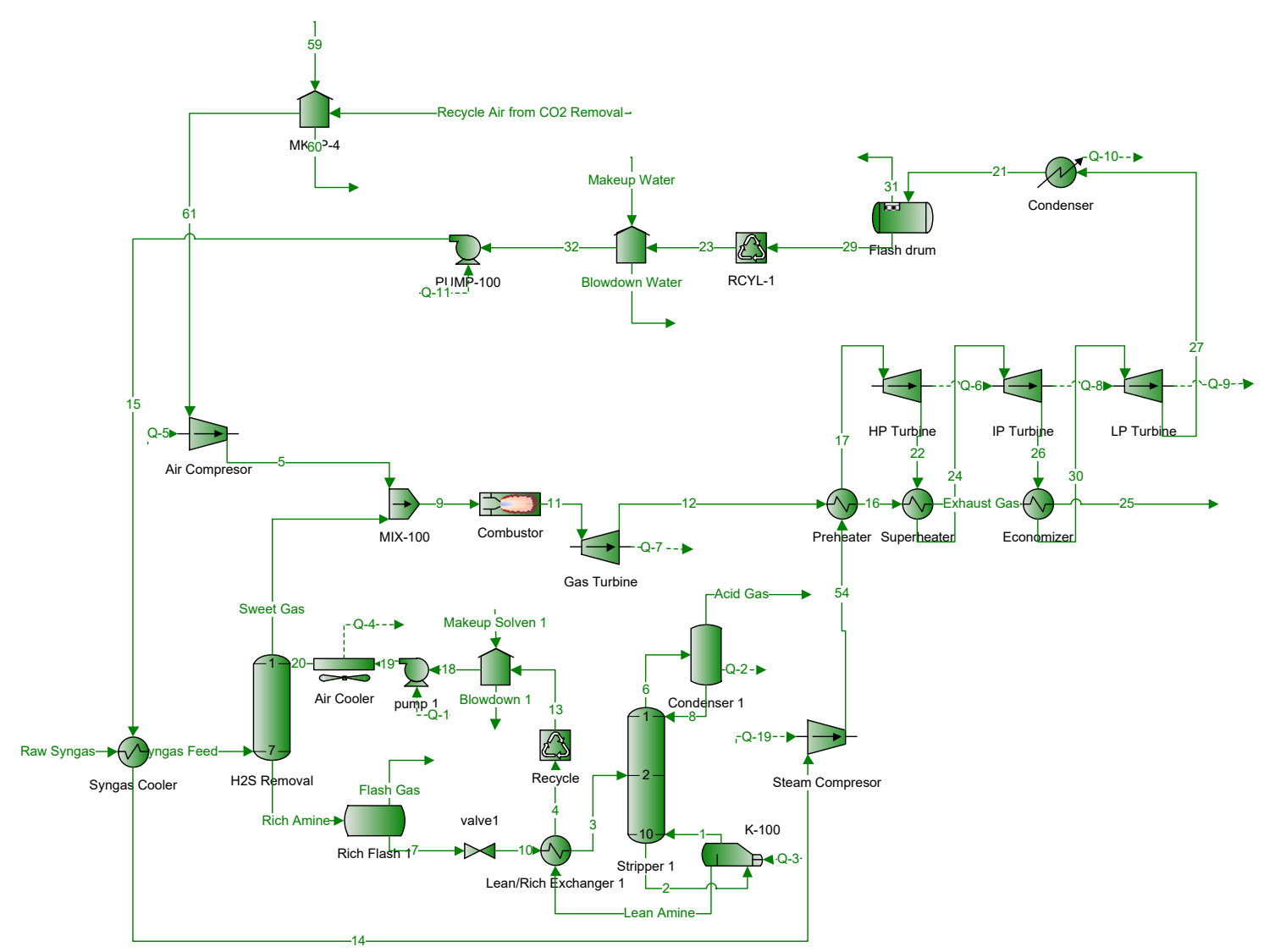

Fig. 3: Schematic of the IGCC system with Promax ${ }^{\circledR} 4.0$

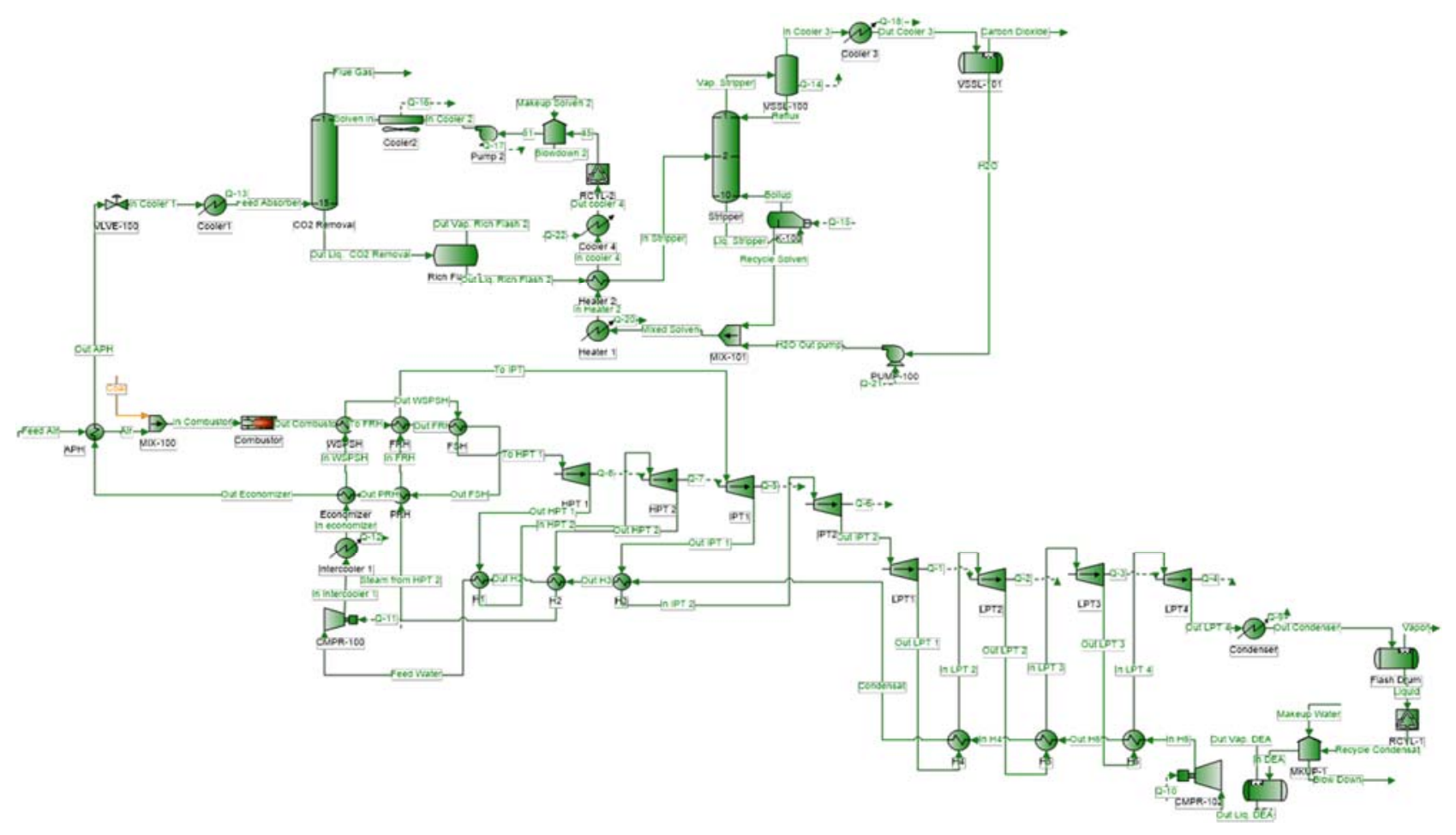

Fig. 4: Schematic of the USC system with Promax ${ }^{\circledR} 4.0$ 


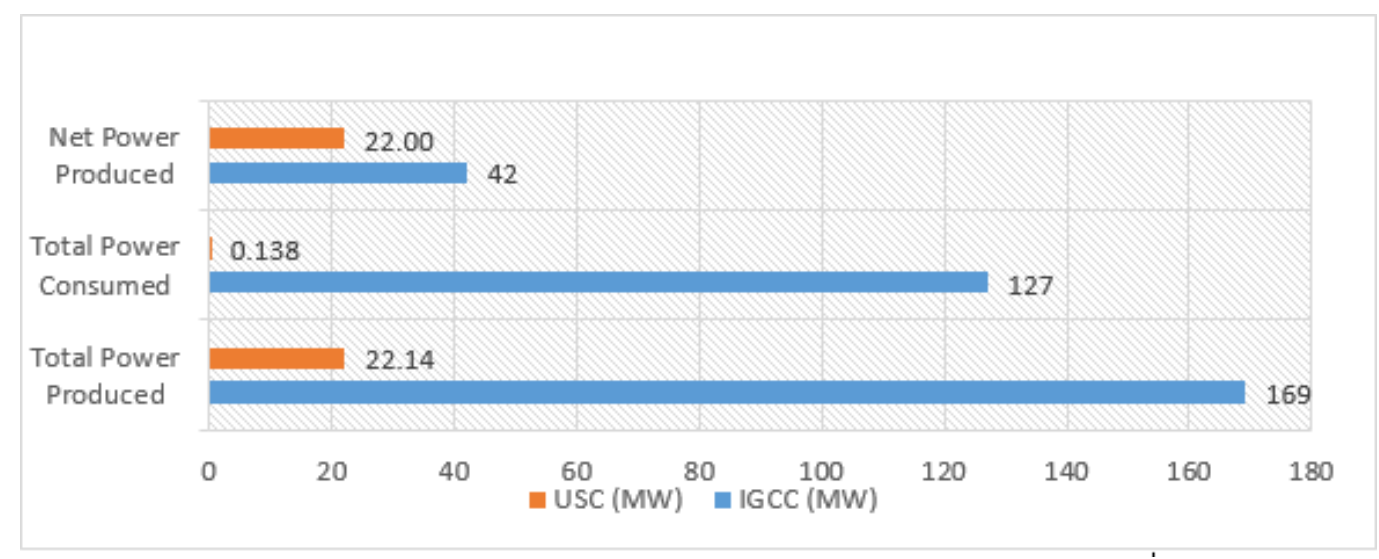

Fig. 5: Comparison of the total power generated and consumed in IGCC and USC

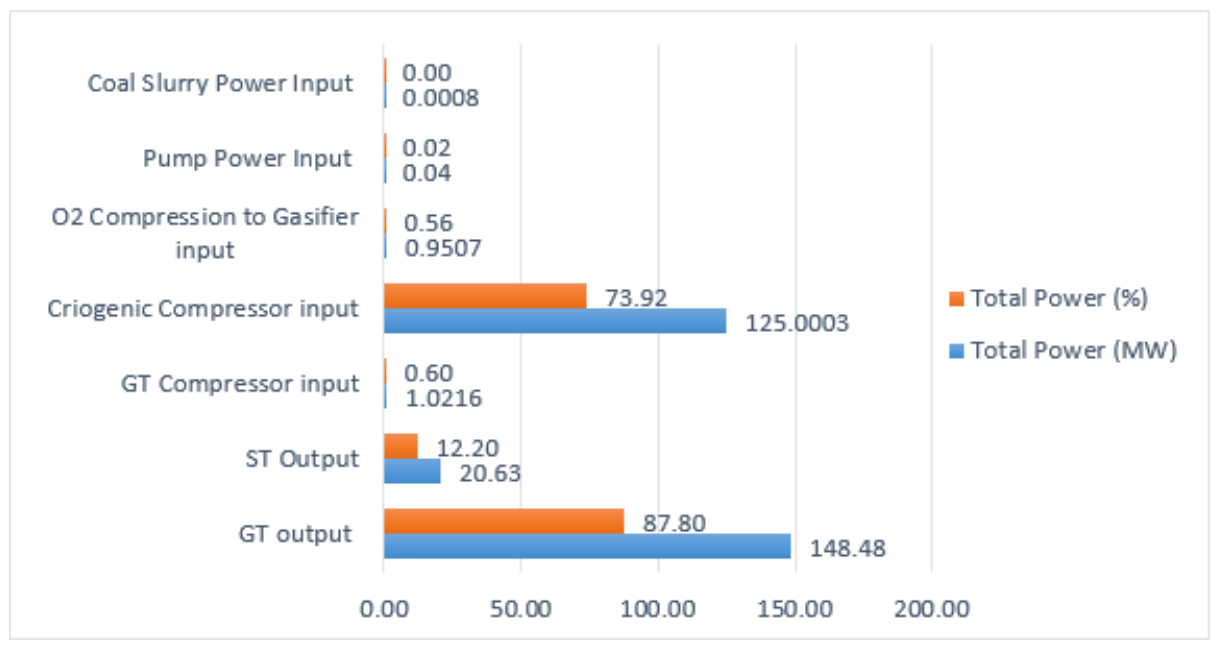

Fig. 6: The power consumed and produced in IGCC section

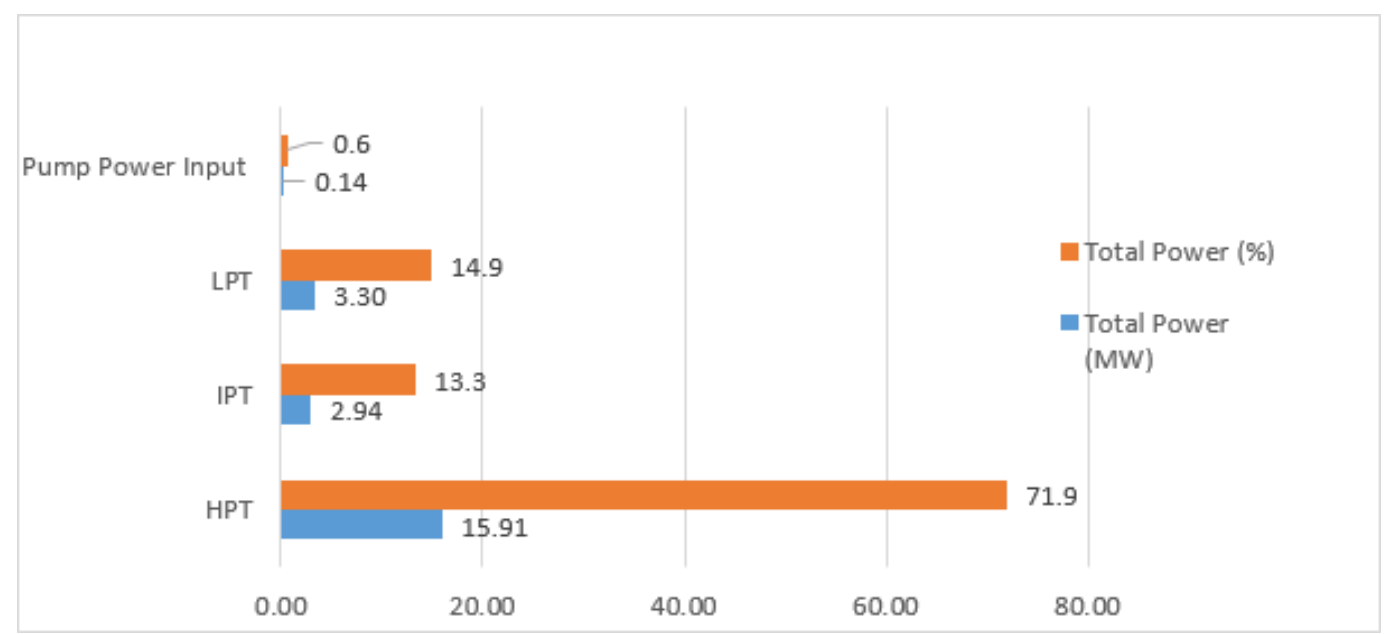

Fig. 7: The power consumed, and the power produced in USC section

The results indicate that $43.19 \%$ of the efficiency exergy in the gasifier, $99.29 \%$ in the syngas Cooler, $66.845 \%$ in the $\mathrm{H}_{2} \mathrm{~S}$ Removal, $98.966 \%$ in the combustor, $71.286 \%$ in the Air Compressor, $94.747 \%$ in the Gas Turbine, $44.115 \%$ in the Steam Turbine system, $94.057 \%$ in the HRSG and then $92.034 \%$ in the Carbon Capture.
For USC the efficiency exergy, was $80.98 \%$ in the Boiler subsystem, $96.37 \%$ in the Steam Turbine system, $98.75 \%$ in the Regenerative Heating System, $5.33 \%$ in the Condenser and $99.75 \%$ in the Carbon Capture. For IGCC the highest exergy losses is in the unit gasifier, $\mathrm{H}_{2} \mathrm{~S}$ Removal, and Carbon Capture, and the USC the highest exergy losses in the Boiler ST system and condenser. 
The low efficiency of the gasifier and boiler or combustor besides being caused by the loss of chemical exergy related to chemical reactions is also caused by the quality of coal fuel, especially in the water content. In coal gasifier which is fed in the form of slurry which still contains a lot of water. The water content causes heat loss due to the evaporation process of the water content in the fuel. The higher the water content in the fuel, the greater the heat loss ${ }^{20)}$.

Table 4. Exergy Loss in the IGCC Technology

\begin{tabular}{lcccc}
\hline Unit & Ex in (MW) & Ex out $(\mathbf{M W})$ & Ex loss (MW) & Efficiency Exergy (\%) \\
\hline Gasifier & 240.8101 & 104.006 & 136.8041 & 43.190 \\
Syngas Cooler & 130.8023 & 129.873 & 0.929 & 99.290 \\
H2S Removal & 1372.542 & 917.4821 & 455.0601 & 66.845 \\
Combustor & 107.4737 & 106.3621 & 1.111616 & 98.966 \\
Air Compressor & 269.5452 & 192.1483 & 77.39697 & 71.286 \\
Gas Turbine & 107.4737 & 101.8279 & 5.645845 & 94.747 \\
Steam Turbine system & 179.9273 & 79.37548 & 100.5518 & 44.115 \\
HRSG & 681.6483 & 641.1367 & 40.51166 & 94.057 \\
Carbon Capture & 2661.872 & 2449.836 & 212.0361 & 92.034 \\
Total & 101.41 & 42.09 & 59.32 & 41.51 \\
\hline
\end{tabular}

Table 5. Exergy Loss in the USC Technology

\begin{tabular}{lcccc}
\hline \multicolumn{1}{c}{ Unit } & $\begin{array}{c}\text { Ex in } \\
\text { (MW) }\end{array}$ & $\begin{array}{c}\text { Ex out } \\
\text { (MW) }\end{array}$ & $\begin{array}{c}\text { Ex loss } \\
\text { (MW) }\end{array}$ & $\begin{array}{c}\text { Efficiency } \\
\text { Exergy (\%) }\end{array}$ \\
\hline Boiler & 1223.36 & 990.64 & 232.72 & 80.98 \\
Steam Turbine & 610.40 & 588.26 & 22.14 & 96.37 \\
Regenerative Heating system & 806.12 & 796.08 & 10.03 & 98.75 \\
Condenser & 26.45 & 1.409 & 25.045 & 5.33 \\
Carbon Capture & 1726.36 & 1722.13 & 4.23 & 99.75 \\
Total & 65.26 & 22.003 & 43.26 & 33.71 \\
\hline
\end{tabular}

\section{Conclusion}

This study to evaluate and compare the performance of coal fire power plants between IGCC and USC. Both of them processes are modeled and simulated with Unisim and Promax program, and exergy analysis and net power produced used to evaluate the results. The following conclusions can be derivate:

- The net power produced in IGCC was $42 \mathrm{MW}$ and in USC was $22 \mathrm{MW}$. While the power produced with USC is the lowest ${ }^{8,12)}$. That is the next study optimization of coal flow rate is needed to produce an optimum net power.

- The relatively higher exergy losses for IGCC in the gasifier, $\mathrm{H}_{2} \mathrm{~S}$ Removal, and Carbon Capture, this is caused by the chemical exergy that is lost and the occurrence of chemical reactions in the gasifier and Gas Turbine combustor. For USC the relatively higher exergy losses in the Boiler Steam Turbine system and condenser.

- The total exergy efficiency for IGCC was $41.51 \%$ and $33.71 \%$ in USC.

for further research needed an economic calculation to determine the feasibility of coal fire power plants between ultra-supercritical (USC) and integrated gasification combined cycle (IGCC).

\section{Acknowledgements}

The author would like to thank for the support provided by all parties involved in writing this paper especially the mentors, Universitas Indonesia which has funded this research through the scheme of Hibah Publikasi Internasional Terindeks Untuk Tugas Akhir Mahasiswa (PITTA B) No. NKB-0691/UN2.R3.1/HKP.05.00/2019 and Institut Teknologi Indonesia.

\section{Nomenclature}

Ex exergy (MW)

LHV low heating value $\left(\mathrm{J} \mathrm{kg}^{-1}\right)$

$T_{0} \quad$ temperature of the dead state $(\mathrm{K})$

$\mathrm{P}_{0} \quad$ pressure of the dead state $(\mathrm{kPa})$

$h \quad$ specific enthalpy $\left(\mathrm{J} \mathrm{kg}^{-1}\right)$

$S_{0} \quad$ entropy of the dead state $\left(\mathrm{J} \mathrm{kg}^{-1} \mathrm{~K}^{-1}\right)$

s entropy of initial state

$h_{0} \quad$ enthalpy of the dead state $\left(\mathrm{J} \mathrm{kg}^{-1}\right)$

w weight fraction (-)

$x \quad$ Mole fraction of syngas (-) 


$$
\begin{array}{ll}
L H & \text { latent heat }(\mathrm{kJ} / \mathrm{kg}) \\
R & \text { Gas law constant }\left(\mathrm{m}^{3} \mathrm{kPa} \mathrm{kmol}^{-1} \mathrm{~K}^{-1}\right)
\end{array}
$$

\section{Greek symbols}

$\begin{array}{ll}\eta & \text { Efficiency exergy }(-) \\ \emptyset & \text { Coefficient to solid fuel composition }(-)\end{array}$

$\begin{array}{ll}\text { Subscripts } & \\ c h & \text { chemical } \\ p h & \text { physical } \\ k & \text { kinetic } \\ p & \text { potential } \\ i & \text { Component index } \\ c & \text { carbon } \\ f & \text { fuel } \\ h & \text { hydrogen } \\ n & \text { nitrogen } \\ s & \text { sulfur } \\ w & \text { water } \\ o x & \text { oxygen }\end{array}$

\section{References}

1) T. I. o. E. E. (IEEJ), " Outlook 2018, Prospects and challenges until 2050, Energy, Environment and Economy.," (2018). https://eneken.ieej.or.jp (accessed Desember 10, 2018).

2) I. E. Agency, "Energy Efficiency 2017 Indonesia,". https://webstore.iea.org/energy-efficiency-2017indonesia-focus-bahasa-indonesia (accessed January 20, 2019).

3) S. J. D. E. Nasional, "Outlook Energi Indonesia 2016," Jakarta Selatan ISSN 2527-3000, (2016). https://www.esdm.go.id/assets/media/content/outloo k_energi_indonesia_2016_opt.pdf (accessed Desember 10, 2018).

4) Y. Liu, Q. Li, X. Duan, Y. Zhang, Z. Yang, and D. Che, "Thermodynamic analysis of a modified system for a $1000 \mathrm{MW}$ single reheat ultra-supercritical thermal power plant," Energy, 145, 25-37, (2018). https://doi.org/10.1016/j.energy.2017.12.060

5) S. D. S. M. Cahyadi, Dwika Budianto, Hari Yurismono, Toorsilo Hartadi, Darmawan, Ahsonul Anam, Sugiono, Yulianto S. Nugroho, Adi surjosatyo," "PLTU Batubara Superkritikal Yang Efisien," 978-602-1124- 94-9, (2015). https://b2tke.bppt.go.id (accessed Desember 20, 2018)

6) Z. Zhao et al., "Exergy analysis of the turbine system in a $1000 \mathrm{MW}$ double reheat ultra-supercritical power plant," Energy, 119, 540-548, (2017). doi: https://doi.org/10.1016/j.energy.2016.12.072

7) L. Zhou, C. Xu, G. Xu, S. Zhao, and Y. Yang, "Parametric analysis and process optimization of steam cycle in double reheat ultra-supercritical power plants," Applied Thermal Engineering, 99, 652-660, (2016).

doi: https://doi.org/10.1016/j.applthermaleng.2016.01.04 7

8) Y. Yang, L. Wang, C. Dong, G. Xu, T. Morosuk, and G. Tsatsaronis, "Comprehensive exergy-based evaluation and parametric study of a coal-fired ultrasupercritical power plant," Applied Energy, 112, 1087-1099, (2013). doi: doi: https://doi.org/10.1016/j.apenergy.2012.12.063

9) Si, N., Zhao, Z., Su, S., Han, P., Sun, Z., Xu, J., Xiang, J. Exergy analysis of a $1000 \mathrm{MW}$ double reheat ultrasupercritical power plant. Energy Conversion and Management, 147, 155-165. (2017). doi:https://doi.org/10.1016/j.enconman.2017.05.045

10) Y. Li, L. Zhou, G. Xu, Y. Fang, S. Zhao, and Y. Yang, "Thermodynamic analysis and optimization of a double reheat system in an ultra-supercritical power plant," Energy, 74, 202-214, (2014). doi: https://doi.org/10.1016/j.energy.2014.05.057

11) Ł. Kowalczyk, W. Elsner, P. Niegodajew, and M. Marek, "Gradient-free methods applied to optimisation of advanced ultra-supercritical power plant," Applied Thermal Engineering, 96, 200-208, (2016).

doi: https://doi.org/10.1016/j.applthermaleng.2015.11.09 1

12) M. Asif, C.-u. Bak, M. W. Saleem, and W.-S. Kim, "Performance evaluation of integrated gasification combined cycle (IGCC) utilizing a blended solution of ammonia and 2-amino-2-methyl-1-propanol (AMP) for $\mathrm{CO}_{2}$ capture," Fuel, 160, 513-524, (2015). doi: https://doi.org/10.1016/j.fuel.2015.08.008

13) L. Han, G. Deng, Z. Li, P. Liu, and Y. Fan, "Influences of syngas pretreatment on the performance and energy distribution in an IGCC power plant," Chemical Engineering Research and Design, 131, 117-126, (2018). doi: https://doi.org/10.1016/j.cherd.2017.12.007

14) R. Hoya and C. Fushimi, "Thermal efficiency of advanced integrated coal gasification combined cycle power generation systems with low-temperature gasifier, gas cleaning and $\mathrm{CO} 2$ capturing units," Fuel Processing Technology, 164, 80-91, (2017). doi: 10.1016/j.fuproc.2017.04.014

15) E. Suarna, "Perkembangan Teknologi Batubara Bersih Berwawasan Lingkungan," Teknik Lingkungan, 12, 25-34, (2011). http://ejurnal.bppt.go.id/index.php/JTL/article/view/ 1259 (accessed January 28, 2019)

16) H. G. Co., "People's Republic of China: Tianjin Integrated Gasification Combined Cycle Power Plant Project," https:/www.adb.org/projects/42117013/main (accessed November 28, 2018)

17) F. Boylu, H. Dinçer, and G. Ateşok, "Effect of coal particle size distribution, volume fraction and rank on 
the rheology of coal-water slurries," Fuel Processing Technology, 85, 4, 241-250, (2004). doi:https://doi.org/10.1016/S0378-3820(03)00198-X

18) T. Wang, "An overview of IGCC systems," in Integrated Gasification Combined Cycle (IGCC) Technologies, 1-80, (2017). doi: https://doi.org/10.1016/B978-0-08-100167-7.000019

19) M. Hofmann and G. Tsatsaronis, "Comparative exergoeconomic assessment of coal-fired power plants - Binary Rankine cycle versus conventional steam cycle," Energy, 142, 168-179, (2018). doi: https://doi.org/10.1016/j.energy.2017.09.117

20) Purba, E, R., Analisis Eksergi Proses Produksi Gula Untuk Meningkatkan Efisiensi Energi pada Sistem Kogenerasi. (2013). http://lib.ui.ac.id/file?file=pdf/abstrak20349915.pdf (accessed February 20, 2018)

21) Wang, X., Yang, Y., Zheng, Y., \& Dai, Y. Exergy and exergoeconomic analyses of a supercritical $\mathrm{CO}_{2}$ cycle for a cogeneration application. Energy, 119, 971-982, (2017).

doi:https://doi.org/10.1016/j.energy.2016.11.044

22) Wu, C., Wang, S.-s., Feng, X.-j., \& Li, J. Energy, exergy and exergoeconomic analyses of a combined supercritical $\mathrm{CO}_{2}$ recompression Brayton/absorption refrigeration cycle. Energy Conversion and Management, 148, 360-377, (2017). doi:https://doi.org/10.1016/j.enconman.2017.05.042

23) Zhaofenga, X., Hetlan, J., Kvamsda, H, M., Zheng, L., Lianbo, L. Economic evaluation of an IGCC cogeneration power plant with CCS for application in China. Energy Procedia, 4, 1933-1940. (2011). doi: https://doi.org/10.1016/j.egypro.2011.02.07

24) Liu, Y., Li, Q., Duan, X., Zhang, Y., Yang, Z., \& Che, $D$. Thermodynamic analysis of a modified system for a $1000 \mathrm{MW}$ single reheat ultra-supercritical thermal power plant. Energy, 145, 25-37, (2018). doi:https://doi.org/10.1016/j.energy.2017.12.060

25) Knoope, M. M. J., Meerman, J. C., Ramírez, A., \& Faaij, A. P. C. Future technological and economic performance of IGCC and FT production facilities with and without $\mathrm{CO}_{2}$ capture: Combining component based learning curve and bottom-up analysis. International Journal of Greenhouse Gas Control, 16, 287-310, (2013). doi:https://doi.org/10.1016/j.ijggc.2013.01.002

26) D. M. Abouelella, S. K. Fateen, and M. M. K. Fouad, "Multiscale Modeling Study of the Adsorption of $\mathrm{CO}_{2}$ Using Different Capture Materials," Evergreen Joint Journal of Novel Carbon Resource Sciences \& Green Asia Strategy, 05, 01, 43-51, (2018). www.tj.kyushuu.ac.jp/evergreen/contents/.../Pages\%2043-51.pdf (accessed August 20, 2019)

27) H. Akamine, M. Mitsuhara, M. Nishida, "Developments of Coal-Fired Power Plants: Microscopy Study of Fe-Ni Based Heat-Resistant
Alloy for Efficiency Improvement, " Evergreen Joint Journal of Novel Carbon Resource Sciences \& Green Asia Strategy, 03, 02, 45-53, (2016). http://www.tj.kyushuu.ac.jp/evergreen/contents/EG2 016-3-2_content/Pages\%2045-53.pdf (accessed August 20, 2019) 